\title{
Fluoroquinolone-Resistant Alcaligenes faecalis Related to Chronic Suppurative Otitis Media, Angola
}

\section{Matuba Filipe, Âke Reimer, Erika Matuschek, Maria Paul, Tuula Pelkonen, Kristian Riesbeck}

Author affiliations: Hospital Josina Machel, Luanda, Angola (M. Filipe); Slottsstadens Läkarhus, Malmö, Sweden ( $\AA$. Reimer); Faculty of Medicine Lund University, Malmö ( $\AA$. Reimer, M. Paul, K. Riesbeck); EUCAST Development Laboratory, Central Hospital, Växjö, Sweden (E. Matuschek); Children's Hospital, Helsinki University Hospital; and Helisinki University, Helsinki, Finland (T. Pelkonen)

DOI: https://doi.org/10.3201/eid2310.170268

We found that $20(10.6 \%)$ of 188 patients with chronic suppurative otitis media in Angola were co-colonized with fluoroquinolone-resistant Alcaligenes faecalis, commonly found in birds. A likely explanation for our findings was the use of bird feces by residents as a traditional remedy to prevent ear secretions caused by primary ear infection.

$\mathrm{C}$ hronic suppurative otitis media (CSOM) is a common condition in developing countries and in original populations such as the Inuit (1). Mainly, young children are reported to have CSOM; $30 \%-40 \%$ of the population are affected in some geographic areas (2). CSOM is associated with hearing loss caused by perforation of the tympanic membrane, which often leads to chronic infection of the middle ear. Overcrowding, poor hygiene, and low nutrition status, in addition to absence of modern healthcare systems, are contributing factors for CSOM (2). CSOM is caused by a polymicrobial infection including gram-negative species, dominated by Pseudomonas aeruginosa and Proteus mirabilis, in addition to gram-positive bacteria such as enterococci and staphylococci (3).

During studies of ear disharge caused by otitis media, we detected the gram-negative bacillus Alcaligenes faecalis in addition to the commonly isolated bacterial species (3). A. faecalis may reside in the human microbiome of the gastrointestinal tract but only occasionally causes disease. Most cases occur in immunocompromised hosts, but in rare instances, A. faecalis infection has been described in patients who had acute otitis media, peritonitis, and eye or urinary tract infections (4-6). A. faecalis is frequently found in bird fecal specimens and can also cause opportunistic infections in these animals (7).

We examined specimens from 188 patients who had ear discharge related to otitis media who attended an outpatient ear, nose, and throat clinic in Luanda, Angola, during January-December 2016. This study was approved by the Angolan Medical Council, the director of the Josína Machel Hospital, and the Luanda University Medical Faculty. After cleaning the ear canal with $70 \%$ ethanol, we collected discharge with a swab. For nasopharyngeal sampling, we inserted a swab into the nostril past the choana and touched the wall of the nasopharynx. We collected ear and nasopharyngeal samples and stored them in skim milk-tryptone-glucose-glycerol (STGG) medium (8) at $-70^{\circ} \mathrm{C}$ (Public Health Laboratory, Luanda, Angola) before transport to the Riesbeck Laboratory (Malmö, Sweden). Clinical specimens were cultured and bacteria analyzed (online Technical Appendix, https://wwwnc.cdc. gov/EID/article/23/10/17-0268-Techapp.pdf). We found that $20(10.6 \%)$ patients were colonized by A. faecalis (Table). Among patients harboring A. faecalis, 14 were male (1-47 years of age) and 6 were female (2-23 years of age). A. faecalis was growing in polymicrobial communities, and $P$. aeruginosa was the predominant species in $10(50 \%)$ of the patients. Proteus mirabilis was the second most common bacterium $(\mathrm{n}=7)$, followed by Klebsiella spp. and gram-positive cocci. Eight of the patients had otalgia, and the duration of otorrhoea was $>12$ months in 4 of those patients.

We tested $A$. faecalis isolates against a series of selected antimicrobial drugs by using broth microdilution (online Technical Appendix Table) and found 100\% were susceptible to aminoglycoside amikacin, cephalosporins, and colistin. In addition, $90 \%$ were susceptible to gentamicin, tobramycin, and piperacillin/tazobactam, and $75 \%$ were susceptible to trimethoprim/sulfamethoxazole. By contrast, most isolates were resistant to the fluoroquinolones ciprofloxacin (100\%) and levofloxacin (82.6\%).

A. faecalis has been described in patients with CSOM (9), but for us, this observation was initially an enigma. We considered the possibility of a contaminant from the endogenous fecal microbiome. We found, however, that to prevent ear discharge, patients occasionally filled their external auditory canals with dove or pigeon feces. Some patients in the geographic area also used cockroach paste, palm oil, sweet olive oil, sewing machine oil, or breast milk to prevent ear discharge. The origin of $A$. faecalis from birds would be a likely explanation for the appearance of this particular bacterial species among this study cohort.

Topical treatment using antimicrobial drugs in combination with keeping the ear canal clean and dry is the mainstay of therapy for CSOM (10). It remains to be confirmed whether A. faecalis colonization plays a crucial role for disease progression or merely is a contaminant. However, the microbiological findings in this study should be a note of caution because all $A$. faecalis isolates we obtained were 
Table. Co-colonizing bacterial species, clinical characteristics, and demographics of 20 patients colonized with Alcaligenes faecalis who had ear discharge related to otitis media, Luanda, Angola, January-December $2016^{*}$

\begin{tabular}{|c|c|c|c|c|c|}
\hline $\begin{array}{l}\text { Patient } \\
\text { no. }\end{array}$ & Co-colonizing bacterial species & $\begin{array}{c}\text { Patient age, } \\
\mathrm{y} / \mathrm{sex}\end{array}$ & Otalgia & $\begin{array}{c}\text { Otorrhoea type, } \\
\text { duration, mo }\end{array}$ & Neighborhood of residence \\
\hline 1 & $\begin{array}{c}\text { Pseudomonas aeruginosa, Escherichia coli, } \\
\text { Proteus spp., Enterococcus faecalis, } \\
\text { Enterococcus avium }\end{array}$ & $10 / \mathrm{M}$ & No & Unilateral, 1 & Coelho, Viana† \\
\hline 2 & 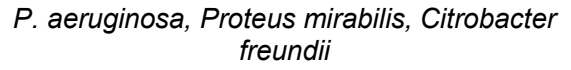 & $8 / F$ & No & Bilateral, $<0.5$ & Cazenga, Cazenga† \\
\hline 3 & $\begin{array}{l}P \text {. aeruginosa, } P \text {. mirabilis, Morganella } \\
\text { morganii, Providencia rettgeri, E. faecalis }\end{array}$ & $20 / \mathrm{M}$ & No & Bilateral, $>3$ & Tala-Hady, Cazenga† \\
\hline 4 & P. mirabilis, C. freundii, E. faecalis & $8 / \mathrm{M}$ & No & Unilateral, $>0.5$ & Hoji-ya-Henda, Cazenga† \\
\hline 5 & $\begin{array}{l}\text { P. aeruginosa, Staphylococcus } \\
\text { saprophyticus }\end{array}$ & $5 / F$ & No & Unilateral, $>12$ & Bairro 6, Viana† \\
\hline 6 & $\begin{array}{c}\text { P. mirabilis, Corynebacterium striatum, } \\
\text { Citrobacter amalonaticus }\end{array}$ & $4 / \mathrm{M}$ & No & Bilateral, $>12$ & Antonove, Cazenga† \\
\hline 7 & Klebsiella pneumoniae, C. freundii & $23 / F$ & Yes & Unilateral, $>12$ & Rangel, Luanda \\
\hline 8 & $\begin{array}{l}\text { P. aeruginosa, Providencia stuartii, } \\
\text { Stenotrophomonas maltophilia }\end{array}$ & $17 / M$ & Yes & Unilateral, >6 & Asa Branca, Cazenga† \\
\hline 9 & $\begin{array}{c}\text { P. aeruginosa, K. pneumoniae, Enterobacter } \\
\text { cloacae, Arthrobacter spp. }\end{array}$ & $20 / F$ & Yes & Unilateral, $<0.5$ & Asa Branca, Cazenga† \\
\hline 10 & $\begin{array}{c}\text { P. aeruginosa, P. mirabilis, K. pneumoniae, } \\
\text { M. morganii }\end{array}$ & $22 / \mathrm{M}$ & Yes & Unilateral, $>12$ & Cazenga, Cazenga† \\
\hline 11 & $P$. aeruginosa, $P$. stuartii, Citrobacter koseri & $7 / F$ & No & Unilateral, $>12$ & Sambizanga, Luanda \\
\hline 12 & No other species $\ddagger$ & $13 / \mathrm{M}$ & No & Unilateral, $>12$ & Saurimo, Saurimo§ \\
\hline 13 & M. morgani & $5 / M$ & Yes & Unilateral, $>12$ & Pimba, Saurimo§ \\
\hline 14 & Arthrobacter spp. $\ddagger$ & $6 / \mathrm{M}$ & No & Bilateral, NA & Saurimo, Saurimo§ \\
\hline 15 & $P$. aeruginosa, Streptococcus constellatus & $14 / \mathrm{M}$ & Yes & Unilateral, $>12$ & Saurimo, Saurimo \\
\hline 16 & P. mirabilis, Arthrobacter spp., E. faecalis & $1 / \mathrm{M}$ & Yes & Unilateral, >3 & Viana, Viana† \\
\hline 17 & $P$. aeruginosa, Klebsiella oxytoca & $2 / \mathrm{M}$ & Yes & Unilateral, $>3$ & Sanzala, Viana† \\
\hline 18 & Arthrobacter spp. $\ddagger$ & $\mathrm{ND} / \mathrm{M}$ & Yes & Unilateral, $>12$ & Tshinganja 2, Saurimoß \\
\hline 19 & Arthrobacter spp., P. stuartii & $47 / \mathrm{M}$ & No & Unilateral, $>12$ & Estalagem, Viana† \\
\hline 20 & Enterococcus faecium & $2 / \mathrm{F}$ & NA & NA, NA & NAI \\
\hline $\begin{array}{l}{ }^{*} A . \text { fae } \\
\dagger \text { Provir } \\
\ddagger A . \text { fae } \\
\text { §Provir } \\
\text { ПProvir }\end{array}$ & $\begin{array}{l}\text { olated from external ear discharge except as indi } \\
\text { anda. } \\
\text { olated from nasopharyngeal swab. } \\
\text { da Sul. } \\
\text { mib. }\end{array}$ & & & & \\
\hline
\end{tabular}

resistant against the most commonly used fluoroquinolone, ciprofloxacin. An alternative strategy would therefore be to consider colistin as topical treatment or supplement with orally administered amoxicillin/clavulanic acid in the treatment of more severe cases. The supply of topical agents in Luanda is unknown; therefore, the optimal treatment of patients colonized with $A$. faecalis should be determined and appropriate supplies obtained.

This work was supported by grants from Foundations of Anna and Edwin Berger (to K.R.) and Gyllenstierna-Krapperup (to K.R. and A.R.), as well as the Swedish Medical Research Council (grant no. K2015-57X-03163-43-4), and Skåne County Council's research and development foundation (to K.R.). Support was also obtained from Päivikki and Sakari Sohlberg Foundation (to T.P.), and the Paediatric Research Foundation (Helsinki, Finland) (to T.P.).

Dr. Filipe is a specialist in otorhinolaryngology (ENT) who has served for more than 25 years as a director of ENT at Hospital Josina Machel and head of the department of ENT at the medical faculty in Luanda (Angola). His primary research interest is the bacteriology and epidemiology of CSOM.

\section{References}

1. Koch A, Homøe P, Pipper C, Hjuler T, Melbye M. Chronic suppurative otitis media in a birth cohort of children in Greenland: population-based study of incidence and risk factors. Pediatr Infect Dis J. 2011;30:25-9. http://dx.doi.org/10.1097/ INF.0b013e3181efaa11

2. Acuin J. Chronic supprative otitis media. Burden of illness and management options. Geneva: World Health Organization; 2004 [cited 2017 Aug 16]. http://www.who.int/pbd/publications/ Chronicsuppurativeotitis_media.pdf

3. Aduda DS, Macharia IM, Mugwe P, Oburra H, Farragher B, Brabin B, et al. Bacteriology of chronic suppurative otitis media $(\mathrm{CSOM})$ in children in Garissa district, Kenya: a point prevalence study. Int J Pediatr Otorhinolaryngol. 2013;77:1107-11. http://dx.doi.org/10.1016/j.ijporl.2013.04.011

4. Bizet J, Bizet C. Strains of Alcaligenes faecalis from clinical material. J Infect. 1997;35:167-9. http://dx.doi.org/10.1016/ S0163-4453(97)91710-2

5. Kahveci A, Asicioglu E, Tigen E, Ari E, Arikan H, Odabasi Z, et al. Unusual causes of peritonitis in a peritoneal dialysis patient: Alcaligenes faecalis and Pantoea agglomerans. Ann Clin Microbiol Antimicrob. 2011;10:12. http://dx.doi.org/10.1186/1476-0711-10-12

6. Pal SS, Panigrahi PK, Roy R, Nandi K, Das S. Endophthalmitis caused by Alcaligenes faecalis: a case series. Ocul Immunol Inflamm. 2013;21:446-8. 10.3109/09273948.2013.817592 http://dx.doi.org/10.3109/09273948.2013.817592

7. Gerlach H. Bacteria. In: Ritchie BW, Harrison GJ, Harrison LR, editors. Avian medicine: principles and applications. Lake Worth 
(FL): Wingers Publishing; 1994. p. 949-83 [cited 2017 Aug 16]. http://avianmedicine.net/content/uploads/2013/03/33.pdf

8. Kaijalainen T, Ruokokoski E, Ukkonen P, Herva E. Survival of Streptococcus pneumoniae, Haemophilus influenzae, and Moraxella catarrhalis frozen in skim milk-tryptone-glucoseglycerol medium. J Clin Microbiol. 2004;42:412-4. http://dx.doi.org/10.1128/JCM.42.1.412-414.2004

9. Obi CL, Enweani IB, Giwa JO. Bacterial agents causing chronic suppurative otitis media. East Afr Med J. 1995;72:370-2.

10. Mittal R, Lisi CV, Gerring R, Mittal J, Mathee K, Narasimhan G, et al. Current concepts in the pathogenesis and treatment of chronic suppurative otitis media. J Med Microbiol. 2015;64:1103-16. http://dx.doi.org/10.1099/jmm.0.000155

Address for correspondence: Kristian Riesbeck, Clinical Microbiology, Dept. of Translational Medicine, Faculty of Medicine, Lund University, Jan Waldenströms gata 59, SE20502 Malmö, Sweden; email: kristian. riesbeck@med.lu.se

\section{Spread of Chikungunya Virus East/Central/South African Genotype in Northeast Brazil}

\author{
Antonio Charlys da Costa, ${ }^{1}$ Julien Thézé, ${ }^{1}$ \\ Shirley Cavalcante Vasconcelos Komninakis, \\ Rodrigo Lopes Sanz-Duro, Marta Rejane \\ Lemos Felinto, Lúcia Cristina Corrêa Moura, \\ Ivoneide Moreira de Oliveira Barroso, \\ Lucineide Eliziario Correia Santos, Mardjane Alves \\ de Lemos Nunes, Adriana Avila Moura, \\ José Lourenço, Xutao Deng, Eric L. Delwart, \\ Maria Raquel dos Anjos Silva Guimarães, \\ Oliver G. Pybus, Ester C. Sabino, Nuno R. Faria
}

Author affiliations: University of São Paulo, São Paulo, Brazil (A.C. da Costa, E.C. Sabino); University of Oxford, Oxford, United Kingdom (J. Thézé, J. Lourenço, O.G. Pybus, N.R. Faria); School of Medicine of ABC (FMABC), Santo Andre, Brazil (S.C.V. Komninakis); Federal University of São Paulo, São Paulo (S.C.V. Komninakis, R.L. Sanz-Duro); Laboratório Central de Saúde Pública Dra. Telma Lobo, Secretaria de Estado da Saúde da Paraíba, João Pessoa, Brazil (M.R.L. Felinto, L.C.C. Moura); Hospital Unimed Maceió, Alagoas, Brazil (I.M. de Oliveira Barroso, L.E.C. Santos, M.R. dos Anjos Silva Guimarães); Hospital Escola Dr. Helvio Auto, Alagoas (M.A. de Lemos Nunes, A.A. Moura); Universidade Federal de Alagoas, Maceió, Brazil (A.A. Moura); Blood Systems Research Institute, San Francisco, California, USA (X. Deng, E.L. Delwart); University of California, San Francisco, California, USA (X. Deng, E.L. Delwart)

DOI: https://doi.org/10.3201/eid2310.170307
We investigated an outbreak of exanthematous illness in Maceió by using molecular surveillance; $76 \%$ of samples tested positive for chikungunya virus. Genetic analysis of 23 newly generated genomes identified the East/Central/South African genotype, suggesting that this lineage has persisted since mid-2014 in Brazil and may spread in the Americas and beyond.

$\mathrm{D}$ engue virus (DENV), Zika virus (ZIKV), and chikungunya virus (CHIKV) co-circulate in Brazil, are predominantly transmitted by Aedes aegypti mosquitoes, and cause similar clinical symptoms upon infection, complicating epidemiologic surveillance. Brazil harbors the highest diversity of CHIKV in the Americas; both the Asian and the East/Central/South African (ECSA) lineages circulate in the country (1). Despite high prevalence of CHIKV in Brazil (352,773 notified cases during January 2016-May 2017) and its widespread distribution (2), little is known about its transmission. We report a molecular and genomic investigation of an outbreak of CHIKV infection in Maceió, Alagoas state, Northeast Brazil.

During March 30-May 3, 2016, ₹12,000 patients visited 2 private hospitals in Maceió; roughly $70 \%$ of them had exanthematous illness symptoms compatible with DENV, CHIKV, or Zika virus infection. We analyzed 273 randomly chosen samples by using molecular diagnostics and virus discovery methods. The study was approved by the Faculty of Medicine from the University of São Paulo Review Board, and we obtained informed consent from all participants.

Analyzed samples were from patients who were on average 37 years of age (range 1-86 years); 175 (64\%) were female, and 198 (73\%) resided in Maceió municipality. Diagnostic tests for DENV, ZIKV, and CHIKV confirmed that $208(76 \%)$ were positive for CHIKV RNA (online Technical Appendix, https://wwwnc.cdc. gov/EID/article/23/10/17-0307-Techapp1.pdf). In addition, 66 (24\%) were positive for Zika virus RNA and 36 (13.2\%) were co-infected with CHIKV and Zika virus, consistent with Zika virus circulation in Northeast Brazil in mid-2016 (3). We detected no DENV infections. Cycle threshold $\left(\mathrm{C}_{\mathrm{t}}\right.$ ) values for CHIKV RNA-positive samples were lower (average $C_{t}=24.6$ ) than those for ZIKV (average $\mathrm{C}_{\mathrm{t}}=33.5$ ).

We applied a metagenomics next-generation sequencing protocol to 38 randomly chosen CHIKV RNApositive samples (4) (online Technical Appendix). We recovered 23 CHIKV genomes ( $>4,000 \mathrm{bp}$ ) by using the MiSeq Sequencer (Illumina, Inc., San Diego, CA, USA); mean genome coverage was $72 \times$ and mean depth coverage 207× (online Technical Appendix Table 1). We also

\footnotetext{
${ }^{1}$ These authors contributed equally to this article.
} 